\title{
Evaluating the Health and Safety Knowledge of Body Waxing Providers in British Columbia
}

\author{
Alicia Parayno ${ }^{1}$, Helen Heacock ${ }^{2}$ \\ 1 Lead Author, B. Tech Student, School of Health Sciences, British Columbia Institute of Technology, 3700 Willingdon Ave, Burnaby. BC V5G 3H2 \\ 2 Supervisor, School of Health Sciences, British Columbia Institute of Technology, 3700 Willingdon Ave, Burnaby. BC V5G 3H2
}

\begin{abstract}
BACKGROUND: Since the deregulation of the BC Cosmetology Act in 2003, esthetics has become a voluntary-certified trade. Considering the rising popularity of more intimate body waxing services and the potential for infections and injuries associated with these services, there is concern that $\mathrm{BC}$ waxing service providers have varying levels of health and safety knowledge.

METHODS: The health and safety knowledge of BC estheticians was analyzed by conducting a knowledge assessment survey of body waxing providers from random clusters of 50 beauty salons in Vancouver and Surrey, BC. To evaluate which parameters affected the estheticians' knowledge scores, ANOVA, t-tests and regression analyses were used. Chi square analyses were used to determine factors associated with the level of esthetics training.

RESULTS: Health and safety knowledge scores widely varied (mean $=18.8 \pm 5.5$ out of 36 points). Estheticians' qualifications were not significantly associated with whether the esthetician started practicing before or after the BC Cosmetology Act deregulation. $84 \%$ held a traditional esthetics certification and 30\% had BeautySafe certification; however they did not necessarily score significantly higher on the health and safety knowledge assessment. Estheticians scored higher in Vancouver than in Surrey $(\mathrm{p}=0.046)$. The cost of waxing $(\mathrm{p}=0.0011)$ and estheticians' perceptions $(\mathrm{p}=0.020)$ of their own knowledge level are also positively related to their knowledge score. Age, alma mater, years of experience, and ethnicity did not show any significant relationship with an esthetician's qualifications or knowledge scores.
\end{abstract}

CONCLUSIONS: Cost of wax treatment, esthetician's perception of health and safety knowledge and location were indicators of an esthetician's health and safety knowledge competency. Consumers should ask the esthetician to rate their own knowledge competency, opt for the more expensive treatment and if they have the option, choose a Vancouver salon over a Surrey salon. The wide range of knowledge scores indicate a gap in health and safety standards and thus, an opportunity for health authorities and the esthetic industry to collaborate to establish such standards.

Key words: body waxing, esthetician, health, safety

\section{Introduction}

According to popular media, it has been an acceptable and even normative practice for women in the Western culture to remove hair from their legs, underarms and bikini line since the early part of the $20^{\text {th }}$ century (Tschachler et al. 2003, SIECAN, 2012). However, there has been a recently growing trend that redefines the ideal of feminine beauty as virtually hairless. (Tschachler et al., 2003; Onstad, 2011, SIECAN, 2012). This trend has also emerged with men (Tschachler et al., 2003; Barnes, 2011).

One popular method of achieving hairlessness is waxing. As one journalist puts it, there seems to be a shift from choice to necessity for women to opt for pubic hair removal via Brazilian waxing (Onstad, 2011). It seems that this is becoming a social norm for younger generations of women. A study found that "women aged 18 to 24 years reported the highest percentage [...] of total hair removal" (SIECAN, 2012).

Despite the introduction of permanent hair removal technology, body waxing continues to be a more popular option than laser hair removal in both women and men (Toerien et al., 2005; Martins et al., 2008; P\&G, 2013). Hence, waxing services, will continue to be popular.

Waxing is a form of mass hair removal (Draelos, 1995). If the treatment is done at a beauty salon by a "professional", it is considered a personal service as it is a service that is provided by a person to or on another person (Ministry of Health, 2013). Esthetic services are a subcategory of personal services, which include make-up application, nail treatments and hair removal by waxing (Alta Reg. 20/2003).

The public health and safety risks of waxing services are not intuitive. Plus, with the current public health focus on more invasive procedures such as body modification, waxing services are being overshadowed. However there have been reports and anecdotes of infections, allergic reactions, burning and scarring associated with waxing services (Lanigan, 2001; Vancouver Sun, 2007; CTV British Columbia, 2006). These services can pose health and safety risks to both clients and service providers. 
Yet, BC regulations on personal service establishments (PSEs) are minimal (BC Reg. 161/2011) and the guidelines for PSEs are a general guide for all PSEs (Ministry of Health, 2013). Other provinces have guidelines for different categories of PSEs, which include more pertinent health and safety guidelines for waxing services. BC has specific guidelines for tattoos, tanning salons, and laser hair removal but there are none for waxing services.

PSEs used to be regulated under the BC Cosmetology Act, but it has been deregulated since 2003. By 2008, the Cosmetology Industry Association of BC claims that it has seen a 3-fold increase in complaints since the deregulation of the Act (CTV British Columbia, 2008).

Considering the deregulation of PSEs and the lack of specific legislation and guidelines in $\mathrm{BC}$, it is difficult to ensure that $\mathrm{BC}$ salons that perform waxing services are practicing adequate health and safety measures. Therefore, the proposed focus of this research project was to ascertain whether BC waxing personnel are adequately knowledgeable to prevent the health and safety risks associated with waxing

\section{.Literature Review}

\section{Waxing Process}

Waxing is a hair removal technique that can be considered as a variation of plucking (Draelos, 1995). It removes the entire hair shaft, including the bulb. Since it removes hair below the skin's surface, waxing is classified as a form of epilation (Ahluwalia, 2009). Unlike plucking, which removes one hair at a time, this technique can be used for mass removal of hair on large areas such as the face, eyebrows, groin, under arms and legs (Draelos, 1995; Bickmore, 2004; Ahluwalia, 2009).

As the name implies, wax is used to remove the hair. It is typically composed of beeswax, oils and a resin, which acts as an adhesive (The Lancet, 1967). There are different methods of waxing such as warm waxing and cold waxing (Draelos, 1995; Ahluwalia, 2009).

Warm waxing, involves low-melting-point waxes (Draelos, 1995). According to Bickmore (2004), the melting point of the wax should be greater than $98^{\circ} \mathrm{F} / 37^{\circ} \mathrm{C}$ but less than $165^{\circ} \mathrm{F} / 73.9^{\circ} \mathrm{C}^{1}$. The melting point needs to be higher than $37^{\circ} \mathrm{C}$, which is the human body temperature, otherwise the wax would not solidify. After heating the wax, the melted wax is applied onto the area of skin with hair to be removed. After the wax cools down, the hair gets entrapped within the wax and it is the stripping off of the wax in the opposite direction of hair growth which removes the trapped hair (Lanigan, 2001;

\footnotetext{
${ }^{1}$ For the purposes of this paper, I will continue to use degrees
} Celsius as this is relevant in Canada
Wanithphakdeedecha and Alster, 2008). The heated wax can be reused.

There are two types of warm waxes: hard wax and soft wax (Bickmore, 2004). Though both require heating before application, hard wax tends to require a lower melting temperature than soft wax. Since hard wax has a lower temperature, it has a thick consistency and it sets faster. $51.6^{\circ} \mathrm{C}-60^{\circ} \mathrm{C}$ is a good temperature range for hard wax upon application (Bickmore, 2004). When it hardens, hard wax is thick enough that it can be removed directly, i.e., without a cloth strip.

Soft wax on the other hand, is more like a liquid on application (Bickmore, 2004). This type of wax requires a cloth strip for hair removal. It is more practical for large areas of hair removal since it is faster and more efficient. However, it adheres to the skin and can result in irritation or other complications. Soft wax would not be appropriate for delicate and fragile skin; instead, hard wax is more suitable since it is able to grip the hairs and lift off the skin.

Cold waxing is a method which uses a liquid wax-like substance or a semi-solid wax at room temperature (The Lancet, 1967; Draelos, 1995). There is no wax-melting step. These are usually more expensive and the semisolid wax can only be used once (Wanithphakdeedecha and Alster, 2008).

If wax treatment leaves behind some stray hairs, tweezers are used to remove the remaining hair (Draelos, 1995). Additionally, tweezers may be used to break skin and remove ingrown hairs (Ministry of Health, 2013).

\section{Health and Safety Risks}

Waxing treatment can be painful for clientele (The Lancet, 1967). It has also been known to cause blood spots, in-grown hairs and skin loss (Bailey and Beswick, 2009). If the service provider has poor technique and improper infection control measures, complications may arise. Though reports of outbreaks or cases are few, there is documented evidence of infections, thermal burns, scarring, folliculitis, skin irritation and allergic dermatitis associated with waxing treatments (Lanigan, 2001; Trager, 2006; Barn and Chen, 2011; Schocker, 2013). As Baily and Beswick aptly state, "this further underlines the fact that only limited research has been conducted on this subject, despite much anecdotal evidence...” (2009).

\section{Review of Reported Infections}

Waxing essentially rips out hair from the skin. This can result in trauma and micro-tears or non-intact skin which makes the skin more susceptible to infection (Trager, 2006; Fritz et al., 2008). It can also produce 
beads of blood or bodily fluids (Alberta Health and Wellness, 2002; CIPHI Ontario, 2011). Aside from transmission of typical skin pathogens such as Staphylococcus aureus and Pseudomonas aeruginosa, waxing theoretically poses blood-borne pathogen risks such as Hepatitis B, Hepatitis C and HIV (Bouwman et al., 1998; Barn and Chen, 2011). The following are documented cases of such infections.

An outbreak of a strain of methicillin-resistant Staphylococcus aureus (MRSA) in the Netherlands was traced back to an infected beautician (Huijsdens et al., 2008). Though she was declared MRSA free in 2005, she tested positive for MRSA again in 2006, which indicated that either she had been re-infected or the treatment had failed. Subsequently, a customer with an abscess of the breast was hospitalized and another customer had boils for months. Both of these clients were infected with the same strain of MRSA as the beautician. Further investigation revealed that they both received wax treatment when the beautician had an infected hair follicle in her armpit. An outbreak investigation led to the screening of 45 individuals who had direct or indirect contact with the beautician. 11 individuals tested positive for MRSA, one was the beautician, 2 were customers and 6 were indirect links, such as family members, roommates and partners. (A couple were infected but an epidemiological link was not found). Environmental swabs of the wax, associated equipment and the treatment room were negative for MRSA. The investigation revealed that the disinfectant used on the skin of clients after waxing, 70\% alcohol, was actually diluted because clients complained about the stinging effects. Furthermore, it was discovered that after waxing, the beautician would check for remaining hairs on the waxed skin using her bare hands, which she did not wash after removing her gloves.

Elmann et al. (2012) evaluated a cohort of 26 female cases of periocular abscess, an inflamed mass containing pus around the eye, following after recent brow epilation (waxing and plucking). Results indicated that these women had acquired infections of methicillin resistant or sensitive $S$. aureus. The authors suspect a combination of factors such as poor personal hygiene and poor sanitization of equipment resulted in the infected periocular abscess. There was another case reported in a CTV BC article about a woman whose eyes became swollen shut after receiving an eye brow wax treatment at a BC salon (2008).

A 20 year old Australian woman with Type 1 diabetes was reported to have developed a group A Streptococcal infection and a recurrence of herpes two weeks after undergoing a Brazilian hot wax treatment at a salon (Dendle et al., 2007). The source of Streptococcus pyogenes was not determined, though the authors suggest potential sources which include the wax, equipment or the service provider. There is also the possibility that waxing resulted in skin trauma, which made the client's skin susceptible to infection from contaminated external sources or from resident microorganisms on her own skin (skin flora), or in this case, the genital area (vaginal flora) This case demonstrates the risk of infection due to waxing services, particularly in immunosuppressed individuals.

Yet, waxing also poses infection risks to immune competent individuals. Zaballos et al. (2002) reported a case of folliculitis due to Mycobacterial chelone infection in an otherwise healthy 32 year-old woman after waxing. They indicated that usually this mycobacterium causes localized skin infections in people with healthy immune systems but it causes several lesions in people with a compromised immune system. However, the 32 year old woman "developed multiple nodular lesions affecting legs, like those immunosuppressed patients with hematogen spread of the disease" (Zaballos et al., 2002).

There are no documented cases of blood-borne pathogen transmission implicated with waxing services. However, Erkek et al. (2007) reported that a 40 year old woman who presented with a rash with purplish discoloration on her inner thighs after waxing was discovered to have Hepatitis $\mathrm{C}$ virus (HCV). Though the report focuses on diagnostic measures and parameters of $\mathrm{HCV}$ rather than a trace back investigation to the source of infection, this paper illustrates that regardless of how she contracted $\mathrm{HCV}$, even if she did not contract it from the waxing services, she is a reservoir for this pathogen. If there are improper infection control procedures at a waxing salon, there is the possibility of infectious transmission from asymptomatic individuals using these services.

All the above cases demonstrate that the several processes and equipment involved during body waxing can play a role in infection transmission (Dendle et al., 2007). As the Netherlands outbreak highlights, infected estheticians and clients can act as (unknowing and asymptomatic) reservoirs and sources of infection if they practice poor personal hygiene (Huijsdens et al., 2008). Surfaces in the salon may be contaminated and improperly disinfected (Fritz, 2008; Elmann 2012). The source of infection can also be the associated equipment and products such as the wax, applicators, cloth strips, tweezers or cream which have been cross-contaminated through the re-use between clients or with the same client (auto-infection). As aforementioned, exposure of nonintact skin to infected individuals and contaminated surfaces or equipment increases the risk of infectious transmission (Trager, 2006; Fritz et al., 2008). 
Recently, research has focused on the hazards of using "open-pot" reusable wax (Barn, 2010). Some beauty salons may use the melting pot of wax between clients and a higher risk of cross-contamination occurs if the service provider "double-dips" the spatula. Though investigations of infections associated with waxing have implicated contaminated reusable warm waxes, either environmental swabs were not performed to confirm the hypothesis or the results were negative (Dendle et al., 2007; Huijsdens et al., 2008). A study by Bailey and Beswick (2009) demonstrates the potential for contamination of "open-pot" wax during use and even prior to use (ex. during packaging, storage).

Bailey and Beswick (2009) developed a method to dissolve body waxes in order to release and identify potential microorganisms contaminating used "openpot" wax products. They obtained samples from twelve salons in the UK of used "open-pot" wax in order to determine the level of contaminating microorganisms compared to unused wax as a control. $78 \%$ of the samples analyzed did not yield any detectable microbial contamination. However 4 used samples and one unused sample yielded "low to moderate numbers of bacteria". In one used sample, an average of 14,000 CFU/gram of bacteria was detected. The common bacteria identified were Bacillus and Staphylococcus. Though the study generally did not find consistently high levels of contamination, it does support the potential for crosscontamination of "open-pot" wax. It should be noted that the authors recognized that the study "represents only a modest cohort of 'real samples', sourced from UK salons within a short time frame." It should also be considered that salons which practice adequate infection control techniques were more likely to participate in the study. Therefore, this study still indicates the need to practice proper infection control techniques (ex. personal hygiene, equipment disinfection and using single-use versus reusable products) to minimize open-pot wax contamination thereby reducing the possibility of infectious transmission.

\section{Allergic dermatitis}

Waxing can also result in allergic reactions. There have been cases of acute allergic contact dermatitis due to the ingredients in wax products (Argila et al., 1996; Gossens et al., 2002). According to a case study by Gossens et al. (2002) from June 2000 to December 2001, "33 cases of acute allergic dermatitis from Veet epilating waxes and/or the accompanying tissue were observed in France and Belgium". As a result of various ingredients in the wax and tissue products, many of these patients had lesions which were severe enough to warrant hospitalization. Not only does waxing present a hazard to clientele, but it also poses an occupational hazard. Argila et al. (1996) reported a case of a beautician who experienced lesions due to handling wax.

\section{Injuries associated with waxing}

There is also the potential that waxing services can cause injuries. The use of hot wax can result in burn injuries (Wanithphakdeedecha and Alster, 2008). A Vancouver Sun article reported that a BC woman who received eyebrow waxing had her "eyelids burned and skin peeled" (2007).

Sometimes clients may be on medications, such as acne medication, which makes their skin fragile for wax treatment. For example, a case report indicated that a 22 year-old female on isotretinoin treatment had received a hot wax treatment to remove facial hair, which resulted in severe erythema and edema on her chin and cheeks (Turel-Ermertcan et. al, 2004). In part, physicians should advise about avoiding hot wax treatment while on the medication. However, waxing service providers should ask clients if they are on any medications prior to performing a treatment.

\section{Legislation on waxing services}

\section{Criticism of BC Legislation, Guidelines, and Procedures}

$\mathrm{BC}$ used to have the Cosmetology Act but that was deregulated in 2003. The current Regulated Activities Regulation (B.C. Reg. 161/2011), under the BC Public Health Act (2008) has a small section regarding PSEs. At most, the BC regulation highlights potable water requirements and mostly focuses on tanning salon requirements rather than the wide scope of personal services. Salons that provide waxing services fall under this regulation and are therefore prescribed as a regulated activity. As such, under the same Act, it is the duty of the operator duty to prevent health hazards, respond to any health hazards that arise and ensure that employees are "adequately trained and sufficiently equipped to recognize, prevent and respond to health hazards that may arise" at the salon. However, the term "adequately trained" is vague. Neither the Public Health Act nor the Regulated Activities Regulation specifies that employees of PSEs in $\mathrm{BC}$ require certification.

Consequently, municipalities vary on their interpretation of adequate training. According to the Beauty Council, the City of Surrey requires that businesses register with the association and that the estheticians are certified through them or an organization called E-Spa (L. Spinner, personal communication, November 20, 2013). However, an article in the Vancouver Sun (2011) reported that by-laws requiring only the owners to be certified were in the process of being drafted in 2011 in Surrey, New Westminster and North Vancouver. There is no indication that estheticianemployees need certification. 
Interestingly, there is a BeautySafe program available in BC (BeautySafe, n.d.). This is a training and certification program that educates beauty professionals on best practices and effective infection protocols. Not only does it have a course on general trade practices, there are modules for specific trades. The Level 2 Esthetics course focuses on infection control procedures, sanitation and chemical practices for waxing, as well as skin care and make-up artistry services. What FOODSAFE is to food premises, BeautySafe is to the cosmetology industry. Yet, while FOODSAFE or an equivalent training program is a prescribed requirement for food premises operators and employees under the Food Premises Regulation (B.C. Reg. 210/99), there is no prescribed provincial requirement for service providers of PSEs to undergo specific health and safety training.

The BC Ministry of Health (2013) Guidelines for personal service establishments provides more direction on personnel hygiene, equipment disinfection and infection control measures than the regulation. However, this document generally addresses the diverse PSEs and it lacks specific sections tailored to different services, such as waxing. The language is also vague. For example, the classification of instruments and equipment as critical, semicritical and noncritical is not clear. For an operator who does not have formal training, this document is long and not as comprehensible as PSE specific guidelines, such as the BC guidelines for tattooing, tanning and laser electrolysis.

Fraser Health provides a standard procedure document specific to waxing treatment (2013). This would be a useful document for operators who do not have BeautySafe or an equivalent form of training for infection control and best practices. However, it lacks sections on preventing burns, asking clients for consent and disclosing risk. It also does not mention personnel getting Hepatitis B immunizations.

Other Canadian provincial legislation, guidelines and procedures

The standards for waxing services vary across Canada, ranging from no provincial legislative oversight to some legislative framework, by-laws, guidelines, and procedures (Rideout, 2010). Alberta ${ }^{2}$, Nova Scotia ${ }^{3}$, New Brunswick $^{4}$ and Newfoundland ${ }^{5}$ have personal services Acts or regulations. However, only Manitoba ${ }^{6}$, Nova Scotia, and New Brunswick provide legislative

\footnotetext{
${ }^{2}$ Personal Services Regulation (Alberta Regulation 20/2003)

${ }^{3}$ Cosmetology Act, 2012

${ }^{4}$ Cosmetology Act, 1998

${ }^{5}$ Personal Services Act, 2012

6 Trade of Esthetician Regulation (MR 13/2007) under The Apprenticeship and Certification Act (C.C.S.M. c.A110)

7 Health Standards and Guidelines for Esthetics (Alberta Health and Wellness, 2002)
}

enforcement on compulsory formal esthetics training or certification.

Alberta $^{7}$, Manitoba $^{8}$ and Ontario ${ }^{9}$ provide infection control guidelines for PSEs. In fact, Alberta's Health Standards and Guidelines for Esthetics is enshrined in their Personal Services Regulation (2003). Yet, Alberta has no requirement for an operating license or permit or health authority approval for a business license. Without this requirement, this makes it difficult to keep track of PSEs. This undermines Alberta's legislative authority. Only Manitoba, Newfoundland, Nova Scotia ${ }^{10}$ and New Brunswick $^{11}$ require licenses or certifications to operate and $\mathrm{BC}$ waxing services only require a business license.

Furthermore, only a few provinces (Newfoundland, Nova Scotia and New Brunswick) have legislative framework for regulating bodies, i.e. public health inspectors, to inspect beauty salons.

With the differing standards and guidelines across Canada, personnel from other provinces who move to $\mathrm{BC}$ to practice may have training or none at all. BC's legislative framework does not provide a strong enough standard to protect British Columbians from salon and personnel who practice less than adequate health and safety measures. This can be mitigated if BC reviews other provincial legislation and guidelines and adopts the best practices.

\section{Proposed study}

The purpose of this project was to determine if differences exist in waxing providers' level of knowledge of health and safety with regards to body waxing services, and if so, evaluate the factors that might play a role in these observed differences. Primarily, the researcher was interested in assessing whether there is a difference in the level of training and consequently, the general health and safety knowledge between $\mathrm{BC}$ waxing service providers who started practicing before versus after the deregulation of the Cosmetology Act. Considering the deregulation and lack of compulsory training and licensing in $\mathrm{BC}$, it was hypothesized that waxing personnel who started practicing after 2003 generally have lower qualifications and subsequently less than adequate knowledge of health and safety issues related to waxing treatment compared to those who started practicing before 2003.

\footnotetext{
${ }^{8}$ Personal Service Facility Guidelines (Manitoba Health, 2012)

${ }^{9}$ Infection Prevention and Control Best Practices for Personal Services Settings (Ontario Ministry of Health and Long-Term Care, 2009)

${ }^{10}$ Cosmetology Association of Nova Scotia by-laws (CANS, 2013).

11 Cosmetology Association of New Brunswick by-laws (CANB, 2013)
} 


\section{Methods and Materials}

\section{Description of materials used}

A standard script and copies of the cover letter, consent form, and survey were printed. Google and Yelp were used to generate a list of BC beauty salons that offer waxing services. The data collected were analyzed with Microsoft Office Excel 2013 and NCSS 8 (Hintze, 2012).

\section{Inclusion and exclusion criteria}

Any English-speaking individual (esthetician) who was at least 19 years old and provided body waxing services in a public beauty spa or salon business anywhere within the province of $\mathrm{BC}$ during the study period was eligible to participate. Excluded from this study were individuals under the age of 19 years old, individuals who did not provide body waxing services in a public beauty business in $\mathrm{BC}$ and all non-BC residents.

\section{Description of method}

Salons in Vancouver and Surrey were approached according to a list of randomized clusters until $\sim 25$ salons from at least 3 different clusters per city responded to the survey. All participants were provided a two-part selfadministered paper-based survey to complete on location at the time of distribution. Part 1 collected information for descriptive statistical purposes (e.g. common demographic questions); Part 2 of the survey assessed the knowledge of the esthetician in terms of health and safety issues related to body waxing treatment. The responses provided by each participant in Part 2 were translated into a numerical score according to a coded answer key.

\section{Reliability and validity of measures}

The questions in Part 1 contained common demographic questions from Statistics Canada, which have been previously prepared and tested (Statistics Canada, 2013). The questions in Part 2, which assessed the participant's knowledge of health and safety, were based on guidelines on infection control and safety with respect to PSEs and body waxing services (Bickmore, 2004; Habia, 2007; BC Ministry of Health, 2013; Dietz, 2013). Furthermore, an esthetics instructor was consulted in the initial survey development process

Since the entire survey had not been previously prepared and tested, to increase validity and reliability, the researcher ran a pilot test (Heacock and Sidhu, 2013). The final survey was presented in a consistent fashion to ensure consistent and accurate measurement (Fowler, 2002; Heacock and Sidhu, 2013).

\section{Ethical considerations}

All things considered, the benefits outweighed the minimal risks. The paper survey itself posed little risk to participants. The questions were reviewed by the instructor-supervisor (Helen Heacock) even before the pilot test. The benefits of the survey included the opportunity to gain knowledge, evaluate the current legislative framework and possibly provide suggestions to policy makers, which would only serve to advance industry standards. The sample of eligible individuals also had the opportunity to provide informed consent (Heacock and Sidhu, 2013). Participants were also assured that their responses would remain confidential and their identity would remain anonymous.

\section{Pilot study}

A non-random sample of 7 estheticians from 4 salons in the Lower Mainland were approached to pilot test the survey. Two non-estheticians were also asked to review the clarity of the language used in the survey.

\section{Results}

\section{Demographics}

The overall response rate was $52 \%$; more specifically, 26/46 estheticians responded in Vancouver versus 24/50 in Surrey. Main reasons cited for non-participation were "busy"; "the boss is not here"; "the waxing esthetician is not here"; and "we no longer perform waxing" - even though the business advertised waxing services. Therefore, the following statistical analyses may be an overestimation or an underestimation of the true value.

The ethnic make-up of the 50 estheticians who responded was diverse (Fig. 1). As expected of a predominantly female industry (Government of Canada, 2012), 49 participants reported being of the female gender while one preferred not to answer. Most of the respondents were between 19 to 39 years old (Fig. 2), which is similar to the results from a previous report (Sage Transitions, 2009). The average years that the sample had worked as an esthetician is 8.9 years (Table 1 ). The average cost of a lower half-leg wax is $\$ 27.7$ with the lowest price at $\$ 12$ and the highest price at $\$ 45$.

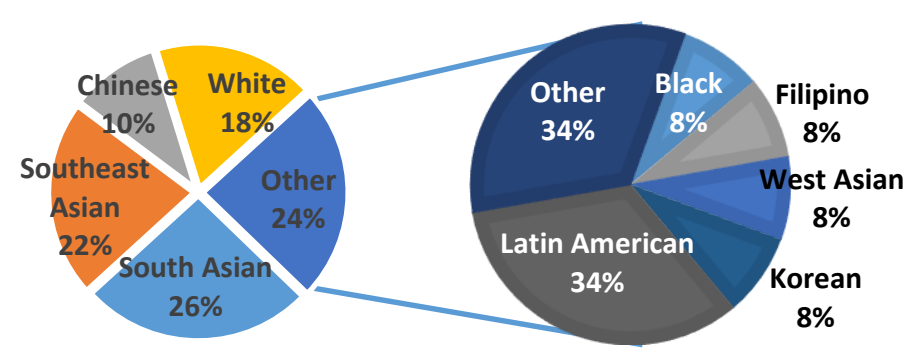

FIG. 1. Ethnicity/Cultural Background of Participants 
TABLE 1. Descriptive statistics of the sample

\begin{tabular}{lccc}
\hline & Years $^{*}$ & Cost** & Score \\
\hline Mean & 8.9 & 27.7 & 18.8 \\
Median & 9.0 & 28.5 & 20.0 \\
Mode & 10.0 & 30.0 & 20.0 \\
Standard Deviation & 5.5 & 7.3 & 5.5 \\
Range & 23.8 & 33.0 & 26.0 \\
Minimum & 0.3 & 12.0 & 4.0 \\
Maximum & 24.0 & 45.0 & 30.0 \\
Sum & 435.4 & 1272.8 & 941.0 \\
\hline
\end{tabular}

*Number of years that sample has worked as an esthetician

**Cost of a lower half-leg wax treatment in Canadian dollars

\section{Qualifications of the estheticians}

Most estheticians reported that they had received traditional or medical esthetics certification (Fig. 3) and almost half trained at either Blanche MacDonald, Vancouver Community College (VCC) or John Casablancas Institute (JCI). Considering the Beauty Council's BeautySafe program was launched in 2012, it was not surprising that the majority, $70 \%$ of the sample, did not indicate they were BeautySafe certified. Interestingly, those who claimed to have BeautySafe training reported receiving it prior to 2012.

Based on the sample of estheticians, there appeared to be no statistically significant association between whether an esthetician started before 2003 or not and the level of esthetics training (chi square, $\mathrm{p}=0.218$ ). The factor that was significantly associated with an esthetician's qualifications was whether it was a minimum requirement to work at the salon (chi square, $\mathrm{p}=0.004)$. Furthermore, whether an esthetician claimed to be BeautySafe certified was associated with their Beauty Council membership status (chi square, $\mathrm{p}=0.0008$ ). Though there was no statistically significant association between ethnic origin and esthetics training or BeautySafe certification (chi square, $\mathrm{p}=0.672$ and $\mathrm{p}=0.058$, respectively), if the study had a larger sample, significant ethnic associations with BeautySafe certification might be more evident. The age, location of

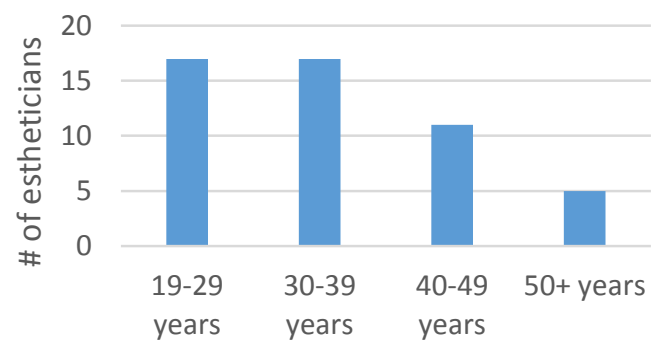

FIG. 2. Age groups of the sample employment, and perception of health and safety knowledge of the esthetician were not associated with qualifications or certification (chi square, $\mathrm{p}>0.05$ ).

\section{Overview of health and safety knowledge assessment of estheticians}

The average knowledge score of the sample as determined by the scores generated from responses to Part 2 of the survey, is $18.8 \pm 5.5$ out of a potential score of 36 . The scores vary from 4 to 30 .

Looking specifically at the responses to each question in the survey some notable observations were made. For the most part, estheticians seemed to be aware not to "double dip" into the wax, although they may not have clearly understood the related question 16. Only one esthetician knew the correct procedure to follow in the event of an accidental blood or body fluid exposure and one esthetician knew about the BC Guidelines for PSEs. More concerning was that only 25/50 estheticians knew that they needed to use a high level disinfectant and were able to name an appropriate product to use if reusable equipment or a work surface was contaminated with blood or body fluids; 5 estheticians stated gluterate and 1 stated UV sterilizer, which are not recommended by the BC Guidelines for PSEs; and the rest either did not know what to use or they stated a lower level disinfectant that was not adequate.
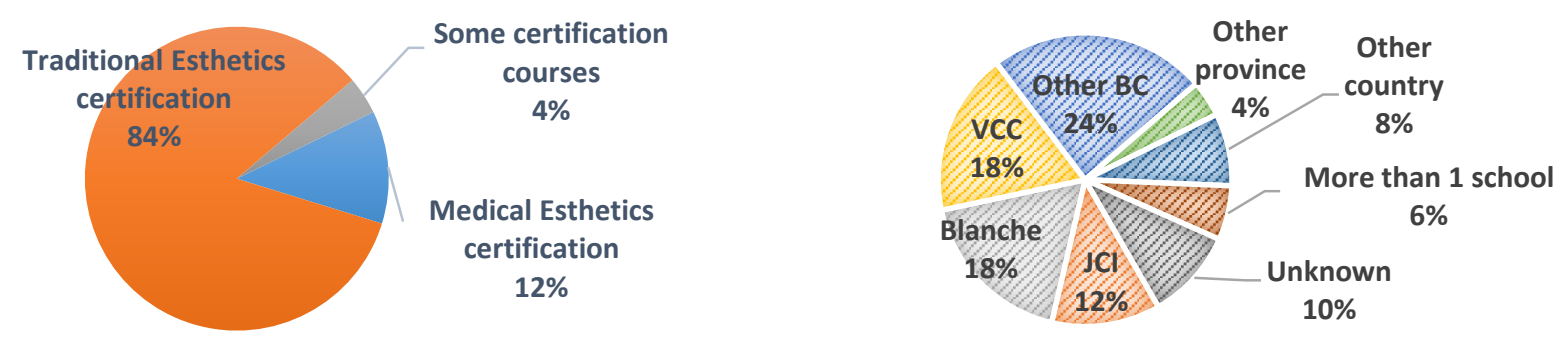

FIG. 3. Esthetics qualifications of sample 


\section{Deregulation had no effect on knowledge score}

As the qualifications of the estheticians were not associated with the deregulation of the BC Cosmetology Act, it follows that there was no significant difference in knowledge scores between start year (Mann-Whitney $U$ 2 -tailed t-test, $\mathrm{p}=0.903$ ). Also counter to expectations, the estheticians did not score significantly different in the health and safety knowledge test based on qualifications (One-Way ANOVA, $\mathrm{p}=0.831$ ) or BeautySafe certification (Equal Variance 2-tailed t-test, $\mathrm{p}=0.195$ ). Years of experience did not statistically correlate with knowledge score (Regression analysis, $\mathrm{p}=0.197$ ).

\section{Self-perception as an indicator of estheticians' health and safety knowledge score}

There appeared to be a statistically significant difference between the estheticians' perceived knowledge level and score (One-Way ANOVA, $\mathrm{p}=0.020$ ). Those who rated themselves fair scored lower $(m e a n=8.5)$ than those who rated themselves good $(m e a n=18.6)$ or excellent (mean=19.4). However, since $\mathrm{p}>0.01$, this may be an $\alpha$ error. Also, the sample sizes between the self-perceived groups are unequal ("fair" $n=2$, "good" $n=9$, "excellent" $n=39$ ).

\section{Salon location affected knowledge score}

When comparing the knowledge scores of estheticians located in Vancouver versus Surrey, there was a statistically significant difference in knowledge scores (Equal variance 2 -tailed t-test, $\mathrm{p}=0.046$ ), though this could present a potential $\alpha$ error. Overall, estheticians in Vancouver scored higher (mean $=20.3$ ) than those in Surrey (mean=17.3). Further One-Way ANOVA analyses indicated that there were no clusters within each city that performed better or worse on the knowledge assessment ( $p>0.05)$. However, there was no statistically significant association between the school attended and whether the esthetician was from Vancouver or Surrey (chi square, $\mathrm{p}=0.337$ ). In fact, the school that the esthetician claimed to have attended did not result in statistically different knowledge scores (One-Way ANOVA, $\mathrm{p}=0.531$ ).

\section{Cost positively correlated with estheticians' knowledge of health and safety}

Cost of wax treatment was statistically correlated with the esthetician's score (Regression analysis, $\mathrm{p}=0.0011$ ). Regression analysis indicated a fair positive relationship $(\mathrm{r}=0.466)$, suggesting that estheticians who were more knowledgeable of health and safety practices, charge more. Since Vancouver estheticians scored higher, it follows that the cost of waxing was found to be statistically higher compared to service in Surrey (Aspin Welch 2-tailed t-test, 0.0498). However, cost did not correlate with years of experience (Regression analysis, $\mathrm{p}=0.965$ ).

\section{Discussion}

According to the results of this study, differences existed in the knowledge competency of the body waxing estheticians in health in safety. Considering that the beauty service industry is a voluntary certified trade it is not surprising that knowledge scores widely varied from 4 to 30. Since the BC Cosmetology Act was deregulated in 2003 and there is no provincial legislation that requires certification for a personal service establishment, it was expected that the differences in health and safety knowledge amongst estheticians were due to a lack of certification, primarily a lack in the cohort that started working after the Act was repealed. From this hypothesis, it followed that, those who started before 2003 should have also scored higher on the health and safety knowledge assessment in Part 2 of the survey. However, the results showed that most of the estheticians in either cohort reported that they possess the traditional esthetics certification. Hence, assuming the estheticians were truthfully certified, there was no difference in esthetic certification between estheticians who started before or after the Act was repealed. As a result, the varying knowledge capabilities of the estheticians could not be explained by certification status.

As most of the estheticians claimed to be certified, perhaps the differences in the knowledge assessment could have been explained by the educational foundation, i.e. the esthetic schools which the estheticians attended. Of the top three schools, Blanche MacDonald Centre is clearly accredited by both the BC Education Quality Assurance (EQA) and Private Career Training Institutions Agency (PCTIA), while John Casablancas Institute is accredited by the PCTIA (PCTIA, n.d.) and the Vancouver Community College is accredited by EQA (EQA, n.d; PCTIA, n.d.). Some of the other schools were accredited, while others were not. There were also a few respondents who did not indicate the name of the school so it was unknown whether or not the program was accredited. As the Estheticians and Spa Professionals Association of British Columbia (n.d.) claim, "schools can determine their own curricula, since there is no legislation or standardization." Yet, there were no apparent statistical differences in knowledge scores based on the alma mater. Interestingly, the highest score was from a Blanche MacDonald graduate while the lowest score was from an esthetician who graduated from an esthetic program outside of Canada. A larger sample size may delineate the true impact of the different schools on the esthetician's knowledge level.

At the very least, regardless of age, location, and ethnic origin, it was assuring to note that most estheticians surveyed had sought certification. Though 
salon requirements for minimum qualifications might have motivated these estheticians to be certified, there were still a few who were voluntarily chose to be certified. Considering that estheticians are willing to undergo certification, there appears to be room for improvement in the esthetics curriculum for the schools, with a stronger emphasis on a provincially standardized health and safety component. Keri et al. (2007) interviewed operators from premier Ontario spas and the respondents compared esthetics training to the massage discipline. They stated that "massage therapists in Ontario and British Columbia undergo the most vigorous and lengthy professional training" while the esthetics education lacked depth and length.

Alternatively, there is opportunity to strengthen the clout of the certification process. In order to receive a certificate, it could be mandatory to pass an infection prevention and control course, such as the Beauty Council BeautySafe course. A report showed that managers, practitioners, educators and students thought that sanitation is one of the more important skills to learn from a training program and that it should require skills certification (Sage Transitions, 2009). Assuming the estheticians were truthful, the results showed that $70 \%$ of the waxing practitioners did not possess a BeautySafe certificate. Certainly, it is a fairly new (or revamped) course so Beauty Council members were more likely to indicate that they were BeautySafe certified. Still, the Beauty Council and health inspectors can raise awareness of this course and even influence legislative bodies to make the BeautySafe certification mandatory like FOODSAFE is for restaurants in BC. However, it must be cautioned that considering the lack of statistically significant differences in knowledge scores of those who were BeautySafe certified or not, the current BeautySafe curriculum may first need to be reviewed.

Interestingly, the results indicated that the estheticians based in Vancouver were generally more knowledgeable with respect to health and safety than those from Surrey. There were no clusters of salons within each city that skewed these results. This would seem to contradict with the notion that the City of Surrey enforces standards on beauty salons, as communicated by a Beauty Council representative. However, it seems that Surrey only enforces that salon owners hold a Beauty Council Certificate of Qualification to be able to apply for a business license. Plus, as mentioned before, training did not appear to account for the differences in knowledge scores.

Therefore, a few possible explanations could account for the differences between the cities. Perhaps there are more salons that consistently strive for high standards of sanitation and safety in Vancouver compared to Surrey. The owner may have selected employees based on their higher competency in sanitation and reiterated the importance of health and safety through in-house training and/or frequent performance reviews. Also, some salons or spas in Vancouver are connected to a school, which were not necessarily the esthetician's alma mater but it still acted as a conduit for reinforcing standards of health and safety. Furthermore, the health inspectors in each city could have played a role in emphasizing certain aspects of health. For example, a few estheticians verbally communicated that double dipping was the norm before, but once the inspector stressed the importance of not double dipping, they changed their behaviour. Maybe Vancouver inspectors visited salons more recently compared to the Surrey inspectors. Some estheticians also indicated that inspectors went through a list of items to inspect. It would have been worthwhile to compare the salon/spa inspection reports that Vancouver and Surrey inspectors use. Nonetheless, these are only speculations and require further exploration.

For the consumer, this study implicates a few indicators of an esthetician's infection control and injury prevention knowledge. Since the cost of a lower half leg wax was statistically correlated with the esthetician's knowledge score, the cost of the wax service could be a fair indicator of knowledge competency, i.e. the higher the price, the more knowledgeable the esthetician is with respect to health and safety. Though there are many factors that goes into pricing, e.g., luxury versus convenient service and location, this seems to also match industry trends as student estheticians at some salons charge less than a full service by an experienced professional. Since the study revealed that wax treatment is priced higher in Vancouver, the results suggest that consumers should find more estheticians with sanitation and safety competency in Vancouver compared to Surrey. The esthetician may also have a more accurate perception of their own knowledge competency, so it may be worth it for the consumer to ask the waxing personnel to gauge their knowledge of health and safety rather than asking for qualifications. Ultimately, if consumers are concerned about a certain aspect of infection prevention and control or safety, it is recommended that they directly ask the esthetician the question. For example, if the consumer is concerned with how they conduct the waxing service, he or she should ask about the details of the process.

Similarly, the health inspector should not rely on qualifications alone and certainly not just the spa owner's qualifications, to assess health and safety competency. The inspector should ask how the esthetician carries out the waxing service. Particularly, the inspector should ask about the details regarding how the practitioner prevents and controls infection prior to, during and after service and in the case of accidental body fluid exposure. 


\section{Recommendations}

Considering that this study showed that most estheticians seek certification and the industry wants to be re-regulated, it is recommended that $\mathrm{BC}$ establishes a standard curricula or certification process for the body waxing industry (as well as other salon services). It is also strongly recommended that it be made mandatory that all estheticians must hold an infection prevention and control and safety certificate relevant to esthetics, which, like FOODSAFE, should be renewed after a certain period (e.g. after 5 years), to ensure that practitioners remain up to date with their health and safety knowledge in the salon (FOODSAFE, 2009). If there is truly a significant association between ethnic groups and being BeautySafe certified, it may be important to have the BeautySafe course materials available in other languages. Furthermore, during each inspection, the inspector should observe each esthetician's practices with respect to body waxing. It is especially important to review disinfection prevention and control procedures.

Public health inspectors can help improve the health and safety standards of the body waxing industry (and other esthetic services) by collaborating with industry professionals and reviewing the infection prevention and control component in an esthetic program and/or the Beauty Council BeautySafe course. Since the esthetic industry wants the trade to be re-regulated, health inspectors should work with the industry to push for the legislative framework that makes, at the very least, BeautySafe certification (or something similar) mandatory. By helping to raise the health and safety standards of the esthetic industry, the health inspector is effectively helping to make their own job of protecting the health of the public a lot easier.

\section{Limitations}

\section{Improvements}

After collecting the data, the researcher realized that some of the questions could have been asked differently. For example, the question regarding double dipping should have been an open-question rather a closed multiple choice question, i.e. what do you do with the wooden spatula after you have dipped it into the wax and applied the wax to the customer? Also, the survey could have asked other questions. For example:

- If you indicated that you are not BeautySafe certified, are you at least aware of the course?

- What year did you graduate from their program?

- Did you receive further in-salon training after you were hired?

- Have you been re-tested, re-trained or have you received frequent performance reviews?
- When was your last health inspection? What items did the health inspectors discuss during inspection?

The responses to these questions could explain the differences between the health and safety knowledge competency between personnel in Vancouver and Surrey. It could also point out areas for improvement.

Also, instead of a paper survey, it could have been an electronic in-person self-administered survey with the use of a tablet. This may minimize inputting error as the data would already be exported in electronic format. Providing the survey in other languages could also make it easier to answer if English is not the esthetician's native language.

\section{Possible errors or bias}

Since the sample size was small, there is a possibility that in truth, differences existed which were imperceptible. A larger sample could have unravelled the true statistical values; however, due to time constraints and budget, it was not possible to survey more. Also, the response rate was not ideal. If there had been a higher response rate, it is possible that the current results are an overestimation or an underestimation of the truth. For example, those who refused to participate in the survey study might be uncertified estheticians who were worried that the researcher was a City official. Furthermore, some questions were left unanswered, which could have impacted the results. These represent a non-response errors (Biemer and Lyberg, 2003; Fink, 2009).

The survey also relies on respondents to answer truthfully. Again, if individuals were apprehensive that the researcher was connected to a government body, they could have claimed to hold a traditional esthetic certificate or a BeautySafe certificate. After all, according to a Beauty Council representative, the current BeautySafe course rolled out in 2012 and yet, those who reported to be BeautySafe certified indicated that they received BeautySafe training before 2012. Alternatively, some estheticians were in a rush to complete the survey to attend their next customer, so it is possible that they were not as attentive as they could have been and responded differently than they would have had they had the time to review the question carefully. Also, though the participants spoke English, for some, it may have been their second language, which would affect their understanding of the question. Furthermore, a few participants were unable to complete the survey at the time of administration. This could have been a disadvantage to respondents as the researcher was not there to clarify questions. These are all examples of measurement error (Biemer and Lyberg, 2003).

Lastly, there could have been errors on the part of the researcher in marking the knowledge assessment, 
manually inputting the data into Excel or NCSS and transcribing it into the report.

\section{Future research suggestions}

For future investigation, it would be interesting to administer the survey to body waxing personnel in other municipalities and/or across provinces for comparison. Other future projects include 1) enlisting the help of individuals who get body waxing treatment to observe the esthetician's practices to determine if the esthetician's knowledge in Vancouver or Surrey translates into practice; 2) surveying the various wax products that estheticians use and testing some of the popular products (at least one hard and one soft wax) to see if melting the wax to "typical" salon temperature is sufficient to kill an inoculum of bacteria; and 3) surveying the disinfection methods of PSEs (not just salons that perform waxing) to determine if they are using the adequate levels and following product directions.

\section{Conclusions}

The findings of this report support the notion that standards with respect to health and safety knowledge vary in the body waxing industry. Assuming that respondents were telling the truth, the results suggest that esthetics training or BeautySafe certification has no bearing on these differences in knowledge competency. As most estheticians were certified, it also shows that counter to the hypothesis, whether an esthetician started before the BC Cosmetology Act was repealed in 2003 or after, it could not account for the varying knowledge level. Years of experience and the school which the esthetician graduated also bears no relationship with a waxing personnel's knowledge in health and safety. Rather, the location of the salon, cost of the wax treatment, and the self-perception of estheticians appear to be better indicators of their health and safety competency. Therefore, it would appear to be worth it for the consumer to opt for the more expensive waxing service, and if possible, choose a salon in Vancouver.

\section{Acknowledgements}

The author thanks Lauren Spinner (BC Beauty Council) and Maria Pillon (Aglaia) for technical information about esthetics, the estheticians at Dr. Heacock's clinic for piloting the survey and Teresita Parayno and David Geere for travel assistance. This work has been funded by BCIT.

Abbreviations: Personal service establishments (PSEs)

Conflict of Interest: The authors declare that they have no competing interests.

\section{References}

1. Ahluwalia, G. (2009). Cosmetic applications of laser and light-based systems. William Andrew Inc: NY.

2. Alberta Health and Wellness. (2002). Health standards and guidelines for esthetics. Retrieved from http://www.health.alberta.ca/documents/StandardsEsthetics.pdf

3. Argila, D., Ortiz-Frutos, J., Iglesias, L. (1996). Occupational allergic contact dermatitis from colophony in depilatory wax. Contact Dermatitis, 34, 369.

4. Bailey, C., \& Beswick, A. (2009). Identification of microbial contamination in body wax samples. (Report no. RR722). Derbyshire, UK: Health and Safety Executive. Retrieved from www.hse.gov.uk/research/rrpdf/rr722.pdf

5. Barn, P., (2010). Waxing: Promising practices fact sheet. Retrieved from http://www.ncceh.ca/sites/default/files/Waxing_Fact _Sheet_Sept_2010.pdf

6. Barn, P., \& Chen, T. 2011. Infections associated with personal service establishments: Aesthetics. Retrieved from http://www.ncceh.ca/sites/default/files/PSE_Infectio ns_Aesthetics_Dec_2011.pdf

7. Barnes, C. (2011). The British Aestheticians Guide to Waxing the Twigs and Berries. AuthorHouse: Bloomington, IN.

8. BC Education Quality Assurance. (n.d.). Find a BC school map. Retrieved from http://www.bceqa.ca/designated-schools/interactivemap

9. BC Ministry of Health. (2013). Guidelines for personal service establishments. Retrieved from http://www.health.gov.bc.ca/protect/pdf/pseguidelines.pdf

10. BeautySafe. (n.d.). BeautySafe. Retrieved from http://www.beautysafe.ca/

11. Bickmore, H. (2004). Milady's Hair Removal Techniques: A Comprehensive Manual. Thomson Delmar Learning: NY.

12. Biemer, P. \& Lyberg, L. (2003). Introduction to survey quality. Hoboken, NJ: John Wiley \& Sons, Inc.

13. Bouwman, R., Cannata, S., Bek, M., and Fett, M. (1998). Infection control and hygiene practices in skin penetration businesses. New South Wales Public Health Bulletin, 9(4), 47-50.

14. CIPHI Ontario. (2011). Waxing. Retrieved from http://www.ciphi.on.ca/images/stories/pdf/fact_sheet s/waxing_2011.pdf

15. Cosmetology Act, New Brunswick Private Bill Legislation (Bill 8) (1998). Retrieved from http://www.canb.ca/pdf/CANB\%20Act\%20Eng.pdf 
16. Cosmetology Act, SNC c. 39 (2012). Retrieved from http://nslegislature.ca/legc/PDFs/annual\%20statutes/ 2012\%20Fall/c039.pdf

17. Cosmetology Association of New Brunswick [CANB]. (2013). 2013 By-laws. Retrieved from http://www.canb.ca/pdf/2013-by-laws-ENG.pdf

18. Cosmetology Association of Nova Scotia [CANS]. (2013). Cosmetology Association of Nova Scotia ByLaws. Retrieved from https://service.clearservice.com/cosmetology/campai gnimages/1/bylaws2013.pdf

19. CTV British Columbia. (2008). B.C. beauty complaints up three times: industry. Retrieved from http://bc.ctvnews.ca/b-c-beauty-complaints-upthree-times-industry-1.342088

20. Dendle, C., Mulvey, S., Pyrlis, F., Grayson, M., \& Johnson, P. (2007). Severe complications of a "Brazilian" Bikini Wax. Clinical Infectious Diseases, 45, e29-31.

21. Dietz, S. (2013). Skin care practices and clinical protocols: A professional's guide to success in any environment. Clifton Park, NY: Milady Cengage Learning.

22. Draelos, Z. (1995). Cosmetics: An overview. Current Problems in Dermatology, 7(2), 45-64.

23. Elmann, S., Pointdujour, R., Blaydon, S., Nakra, T., Connor, M., Mukhopadhyay, C., Levin, F., Schwarcz, R., Shepler, T., Shore, J., Wladis, E., \& Shinder, R. (2012). Periocular abscesses following brow epilation. Ophthalmic Plastic \& Reconstructive Surgery, 28(6), 434-437.

24. Erkek, E., Ayaslioglu, E., Erdogan, S. and Bagci, Y. (2007). Vasculopathic skin lesions following epilation, leading to a discovery of hepatitis $C$ virus infection. Clinical and Experimental Dermatology, 32, 221-222.

25. Estheticians and Spa Professionals Association of British Columbia. (n.d.). Estheticians and Spa Professionals Association of British Columbia. Retrieved from http://espabc.blogspot.ca/p/home.html

26. Fink, A. (2009). How to conduct surveys: A step-bystep guide $\left(4^{\text {th }}\right.$ ed.). Thousand Oaks, CA: Sage Publications, Ltd.

27. FOODSAFE. (2009). Frequently asked questions. Retrieved from http://www.foodsafe.ca/main/faq

28. Fowler, F. (2002). Survey research methods. Thousand Oaks, CA: Sage Publications, Ltd.

29. Fraser Health. (2013). Standard operating procedures for waxing treatment. Retrieved from http://www.fraserhealth.ca/media/Waxing_Treatmen t-Procedures.pdf

30. Fritz, S., Garbutt, J., Elward, A., Shannon, W., \& Storch, G. (2008). Prevalence of and risk factors for community-acquired methicillin-resistant and methicillin-sensitive Staphylococcus aureus colonization in children seen in a practice-based research network. Pediatrics, 121, 1090-1098.

31. Gossens et al. (2002). An epidemic of allergic contact dermatitis due to epilating products. Contact Dermatitis, 46, 67-70.

32. Government of Canada. (2012). Estheticians, electrologists and related occupations. Retrieved from

http://www.servicecanada.gc.ca/eng/qc/job_futures/s tatistics/6482.shtml

33. Habia. (2007). Code of practice for waxing services. Retrieved from http://www.habia.org/uploads/waxing_code_of_prac tice_booklet.pdf

34. Heacock, H., \& Sidhu, B. (2013). ENVH 8400 Research methods lecture notes, BCIT, Burnaby, BC.

35. Hintze, J. (2012). NCSS 8. NCSS, LLC. Kaysville, Utah, USA. www.ncss.com.

36. Huijsdens, X., Janssen, M., Renders, N., Leenders, A., Wijk, P., Santen-Verheuvel, M., van-Driel, J, \& Morroy, G. (2008). Methicillin-resistant Staphylococcus aureus in a beauty salon, the Netherlands. Emerging Infectious Diseases, 14(11), 1797-1799.

37. The Lancet. (1967). Epilatories and depilatories. The Lancet, 289(7488), 488.

38. Keri, K. (2007). The North American spa industry: An examination of emergent trends. Hospitality Review, 25, 50-60.

39. Lanigan, S.W. (2001). Management of unwanted hair in females. Clinical and Experimental Dermatology, 26, 644-647.

40. Manitoba Health. (2012). Personal Service facility guidelines. Retrieved from http://www.gov.mb.ca/health/publichealth/environm entalhealth/protection/docs/psf_guideline.pdf

41. Martins, Y., Tiggeman, M., Churchett, L. (2008). Hair today, gone tomorrow: A comparison of body hair removal practices in gay and heterosexual men. Body Image, 5, 312-316.

42. Microsoft (2013). Microsoft Office Excel (Version 2013). Microsoft Corporation.

43. Onstad, K. (2011). Why has body-hair removal shifted from a choice to a necessity for women? The Globe and Mail. Retrieved from http://www.theglobeandmail.com/life/relationships/ why-has-body-hair-removal-shifted-from-a-choiceto-a-necessity-for-women/article625702/

44. Ontario Ministry of Health and Long-Term Care. (2009). Infection prevention and control best practices for personal services settings. Retrieved from

http://www.health.gov.on.ca/en/pro/programs/public health/oph_standards/docs/pssp_2008.pdf

45. Personal Services Act, SNL c. P-7.2 (2012). Retrieved from 
http://www.assembly.nl.ca/Legislation/sr/statutes/p0 7-2.htm

46. Personal Services Regulation, Alta Reg. 20. (2003). Retrieved from http://www.qp.alberta.ca/1266.cfm?page=2003_020. cfm\&leg_type $=$ Regs\&isbncln $=9780779766390 \&$ dis play $=$ html

47. Private Career Training Institutions Agency. (n.d.). Retrieved from http://www.pctia.bc.ca/listings/accredited

48. Procter and Gamble $[\mathrm{P} \& \mathrm{G}]$. (2013). Female hair removal options. Retrieved from http://www.pgbeautygroomingscience.com/femalehair-removal-options.php

49. Public Health Act, SBC c. 28 (2008). Retrieved from http://www.bclaws.ca/EPLibraries/bclaws_new/docu ment/ID/freeside/00_08028_01

50. Regulated Activities Regulation, B.C. Reg. 161 (2011). Retrieved from http://www.bclaws.ca/EPLibraries/bclaws_new/docu ment/ID/freeside/161_2011

51. Rideout, K. (2010). Comparison of guidelines and regulatory frameworks for personal services establishments. Retrieved from http://www.ncceh.ca/sites/default/files/PSE_Guideli nes_Comparison_Table_July\%202010.pdf

52. Sage Transitions. (2009). Personal services industry labour market research report. BC: Steward, H. \& MacRae, I.

53. Schocker, L. (2013). Bikini waxing dangers: 5 health risks to consider. Huffpost healthy living. Retrieved from http://www.huffingtonpost.com/2013/03/29/bikiniwaxing-dangers-risk-health_n_2976402.html

54. Sex Information and Education Council of Canada [SIECAN]. (2012). Female pubic hair removal. Retrieved from http://sexualityandu.ca/uploads/files/CTR_PubicHair Removal_APR2012-EN.pdf

55. Statistics Canada. (2013). Ethnic origin reference guide, National Household Survey, 2011 (Catalogue no. 99-010-XWE2011006). Ottawa: Government of Canada. Retrieved from http://www12.statcan.gc.ca/nhsenm/2011/ref/guides/99-010-x/99-010-x2011006eng.cfm

56. Toerien, M., Wilkinson, S., \& Choi, P. (2005). Body hair removal: The 'mundane' production of normative femininity. Sex Roles, 52, 399-406.

57. Trade of Esthetician Regulation, MR 13 (2007). Retrieved

from http://web2.gov.mb.ca/laws/regs/pdf/a110013.07.pdf

58. Trager, J. (2006). Pubic hair removal - pearls and pitfalls. Journal of Pediatric and Adolescent Gynecology, 19, 117-123.
59. Tschachler, H., Devine, M., \& Draxlbauer, M. (eds.) (2003). The embodyment of American culture. Münster, Germany: Lit-Verlag.

60. Turel-Ermertcan, A., Sahin, M. Yurtman, D., Kapulu, N., \& Ozturkcan, S. (2004). Inappropriate treatments at beauty centers: A case report of burns caused by hot wax stripping. The Journal of Dermatology, 31, 854-855.

61. Vancouver Sun. (2007). Beauty industry complaints up 10-fold after deregulation. Retrieved from http://www.canada.com/vancouversun/story.html?id $=61 \mathrm{fa} 4 \mathrm{f} 81-8 \mathrm{bdc}-40 \mathrm{a} 9-\mathrm{bb} 32-$

$9 \mathrm{ccc} 88 \mathrm{ed} 483 \mathrm{~b} \& \mathrm{k}=54779$

62. Vancouver Sun. (2011). Day spas scrub up their standards: Beauty association is trying to bring order to unregulated industry. Retrieved from http://www.vancouversun.com/health/spas+scrub+th eir+standards/5882191/story.html

63. Wanithphakdeedecha, R., and Alster, T. (2008). Physical means of treating unwanted hair. Dermatologic Therapy, 21, 392-401.

64. Zaballos, P., Ara, M., Seral, C., Rodero, J., Grasa, M., Agurruza, J. and Carapeto, F. (2002). Foliculitis postdepilación por Mycobacterium chelonae. Actas Dermo-Sifilográficas, 93, 259-262. 